\title{
THE MANAGEMENT OF CHALLENGES RELATED TO THE INNOVATION PROCESS: A MULTI-CASE STUDY IN INDUSTRIES OF THE COSMETIC SECTOR
}

\author{
A GESTÃO DOS DESAFIOS RELACIONADOS AO PROCESSO DE \\ INOVAÇÃO: UM ESTUDO MULTICASO EM INDÚSTRIAS DO \\ SETOR DE COSMÉTICOS
}

Submission: 06/03/2019 Accept: 05/12/2019

\author{
Inayara Valéria Defreitas Pedroso Gonzalez ${ }^{1}$ \\ 1 Federal University of Espírito Santo.
}

\begin{abstract}
Purpose - The objective was to reveal reflections on how the managers of industrial cosmetic companies deal with the challenges related to the innovation process.

Design/methodology/approach - Exploratory qualitative research. The present research uses a combination of methods: theoretical-conceptual, bibliographical survey and the multi-case study, by means of the following procedures: semi-structured interview, observation route and document analysis.

Findings - I concluded that the main challenges faced by the management of the innovation process in the small business are related to the non-development of a culture focused on innovation and not planning the capacity to decentralize. In the case of the medium sized company, the main challenge related to the innovation process is to manage, simultaneously, the growth of the company on the one hand, and the managerial practices aimed at the use of the knowledge of its team, on the other, in the process of innovation. In the case of the large company, I concluded that the challenges of maintaining the integration of the innovation process and, at the same time, the flexibility to transform the way things are done, are well orchestrated by management because there is constant discussion and shared vision, in a spirit of trust and teamwork.

Research limitations/implications - The data cannot be generalized because it is a multi-case study.

Practical implications - As soon as the challenges were identified, the assumption was confirmed that the achievement of innovation implies knowing how to integrate resources and capacities, manage periods of instability or irregularity and regularity, based on a culture focused on strategic learning, learning to learn and, systemic learning.

Originality/value - This exploratory qualitative research contributes with evidences and analyzes on the management of the innovation process in three companies of different sizes, in which are revealed the managerial actions in relation to the innovation requirements that have been explored from the theoretical bases that support the integration of the learning organizational and management of innovation, and the reflections on how manifest the management of the challenges faced in each company.

Keywords - Innovation Process; Challenges of the Innovation Process; Innovation Strategy; Innovation management; Cosmetics Industries.
\end{abstract}




\section{RESUMO}

Objetivo do estudo: O objetivo foi revelar reflexões sobre como os gestores de empresas industriais de cosméticos lidam com os desafios relacionados ao processo de inovação.

Desenho/metodologia/abordagem - Pesquisa exploratória qualitativa que utiliza uma combinação de métodos: teórico-conceitual, levantamento bibliográfico e estudo multicaso, por meio dos seguintes procedimentos: entrevista semiestruturada, roteiro de observação e análise documental.

Resultados - Os principais desafios enfrentados pela gestão do processo de inovação na pequena empresa estão relacionados ao não desenvolvimento de uma cultura voltada à inovação e ao não planejamento da capacidade de descentralização. No caso da empresa de médio porte, o principal desafio relacionado ao processo de inovação é gerenciar simultaneamente o crescimento da empresa de um lado, e as práticas gerenciais voltadas para a utilização do conhecimento de sua equipe, de outro, no processo de inovação. No caso da grande empresa, a conclusão é que os desafios de manter a integração do processo de inovação e, ao mesmo tempo, a flexibilidade para transformar a forma como as coisas são feitas, são bem orquestrados pela gestão porque há discussão constante e visão compartilhada, num espírito de confiança e trabalho em equipe.

Limitações/ Implicações da pesquisa - Os dados não podem ser generalizados por se tratar de um estudo multicaso.

Implicações práticas - Assim que identificados os desafios, confirmou-se o pressuposto de que a conquista da inovação implica saber integrar recursos e capacidades, gerenciar períodos de instabilidade e de estabilidade ou irregularidade e regularidade, a partir de uma cultura voltada para o aprendizado estratégico, o aprender a aprender e, o aprendizado sistêmico.

Originalidade - Esta pesquisa qualitativa exploratória contribui com evidências e análises sobre a gestão do processo de inovação em três empresas de diferentes portes do setor de cosméticos, nas quais são reveladas ações gerenciais em relação aos requisitos de inovação que foram explorados a partir das bases teóricas que sustentam a integração entre a aprendizagem organizacional e a gestão da inovação, e reflexões sobre como se manifesta a gestão dos desafios enfrentados em cada empresa ao longo deste processo.

Palavras-chave - Processo de Inovação; Desafios do Processo de Inovação; Estratégia de Inovação; Gestão da Inovação; Indústria de Cosméticos.

\section{INTRODUCTION}

At the end of the 20th century, in a context of market opening, when quality and productivity were the mottoes, Brazilian companies dealt with the challenges of competition from a difficult implementation of programmed changes and techniques and concepts such as Total Quality Control (TQC), Return on Quality (ROQ) and Reengineering (Fleury \& Fleury, 1995).In the 21st century, themes such as change, innovation and learning are increasingly prominent in debates between academics and market professionals (Fleury \& Fleury, 1995; 2011), in a growing interest in the development of learning cycles capable of relating different ideas, between different people, in a continuous and evolutionary process (Fleury \& Fleury, 2011).

The requirement for these skills, learning and innovation, is amplified when the business assumes the responsibility of preserving the planet and its inhabitants; to think about future generations (Hamel \& Prahalad, 1995). Therefore, new business strategies are inclined to creativity and innovation, both to achieve the generation of profit and to offer contributions to the environment and to society (Hamel \& Prahalad, 1995).

The innovation theme is important both in technically younger productive chains and in more dynamic or more mature chains with long life cycles, because critical factors such as intense international competition, the sophistication of the market and the rapid change of technologies are increasingly present (Dacorso, Yu, Silva, \& Araújo, 2010).

According to Tidd, Bessant and Pavitt (2008), the companies that look for innovation follow 
a process of analysis of the environment, decide which signals to respond to and consider the strategic vision of how the company can best develop itself, then start translating the potential of the idea into something new and proceed to the implementation. From this cycle, we can take advantage of the opportunity to learn from the progression, so that it can build its knowledge base and improve the ways in which the innovation process is managed (Tidd, Bessant \& Pavitt, 2008).

Each innovation process represents a continuous cycle of building and incorporating knowledge and that involves the search, selection and implementation of ideas in a constant progression (Tidd, Bessant \& Pavitt, 2008). In general, innovation processes depend on norms in order for organizations to be able to carry out their innovation activities more efficiently, systematizing them; at the same time, these activities should be flexible in order to increase competitiveness through innovation (Mir \& Casadesús, 2011).

For the emergence of innovation, Amabile, Hadley and Kramer (2002) believe that creativity is the first step. A study conducted by Carneiro (2000) demonstrates that the way creative processes are managed in organizations has a direct influence on their success. Creativity is a theme that according to the Brazilian Association of Consultancy and Advisory in Foreign Trade -ABRACOMEX, is always present in the Personal Hygiene, Perfumery and Cosmetics sector-PHPC, which is capable of meeting the most diverse demands of the world market (ABRACOMEX, 2017)and where the demand for innovation is continuous (Fritz \& Souza, 2006; ABIHPEC, 2012).

In May 2015, with the increase in IPI (Tax on Industrialized Products) and the economic recession that increased unemployment, consumer insecurity was observed and the PHPC sector retreated almost $8 \%$ for the first time in the last twenty years (ABIHPEC, 2016).Given this context and global competition, we analyze that innovation can contribute to the competitive performance of companies and sectors of the economy (Cássia \& Zilber, 2016), but dealing with a global competitive environment means coming to innovative products from the functions and talents to creating a productive whole (Senge, 2002), because the practice of analyzing the market is not enough when the scenario presents new technologies and products, where knowledge management becomes necessary and the concept of innovation is present (Serrano \& Gobbo, 2014). Moreover, in a context of seeking to maintain leadership, the management of the competitive company that seeks continuous improvement, if it is not attentive to the technologies of rupture in its area of action, it leads the company to lose its leadership in the market (Christensen, 1997).

In addition, there is the challenge for managers to know how to use resources and develop the skills necessary to generate competitive differential (Hamel \& Prahalad, 1995).Managers need to be able to adapt the company to the contingencies faced and the strategies need to be adaptive (Abbade, Zaini \& Souza, 2012).

The adoption of the innovation strategy is linked to the strategic orientation of the company established by the businesses management (Cássia \& Zilber, 2016). At the same time, innovation management is a learned capacity and involves developing skills to manage the two aspects of innovation: to do better what one already knows how to do, and doing it, but in a different way (Tidd, Bessant \& Pavitt, 2008). In addition, innovation needs to be accepted in the market and be able to generate profit (OCDE, 2005; Tidd, Bessant \& Pavitt, 2008).

All these challenges linked to the innovation process lead to questions of such kind: how do we build and sustain a cycle of incorporating knowledge and new ideas within the company seeking innovation? How to manage innovation activities efficiently and effectively? How to do better what one already knows how to do, with a difference in order to achieve market acceptance through innovation, and make a profit, concurrently?

Starting from such reflections and questions, this study was driven by the following research problem: How do managers of industrial cosmetics companies deal with the challenges re- 
lated to the innovation process? After all, knowing how they deal with such challenges may reveal learning in relation to the construction of a culture aimed at the emergence of innovation; to highlight possible problems that could be avoided in the innovation management process, in addition to pointing out facilitating factors for the sustainability of this innovation process, with a view to better understanding how to develop the capacity for flexibility to deal with its challenges.

In conceptual terms, Tidd, Bessant and Pavitt (2008) take the innovation process as a continuous cycle of knowledge construction and incorporation and involves the search, selection and implementation of ideas, in a constant progression of learning. Based on this concept of innovation process, this research reveals the challenges associated with this process in the industrial cosmetics companies.

Thus, this research aimed to reveal reflections on the way that managers of industrial cosmetic companies deal with the challenges related to the innovation process. As a theoretical contribution, the aim was to identify the challenges related to the innovation process and reflections on how to deal more effectively with the difficulties associated with coordination and the integration of teams engaged in the activities of the innovation process. Attention to this framework of study is relevant, considering it as recent the group of studies that aims to examine the relationship between behavioral and attitudinal aspects of management and the resource base (Maciel, Sato \& Kato, 2012).

In terms of practical contribution, the managerial mechanisms, present in the innovation process of the companies studied, which contribute to the balance between flexibility and control, important for the emergence of new ideas in the culture of innovation; I also explore the characteristics of managerial behavior aimed at the emergence of meaningful learning, with a view to the emergence of innovations; and I analyzed the importance of creating an organizational policy focused on meaningful and strategic learning, so that the challenges related to the innovation process are better managed towards continuous and evolutionary innovation.

\section{THEORETICAL FRAMEWORK}

From a historical point of view, the innovation process has always existed. First as an informal process, based on empiricism (21st Century); then having the use of scientific knowledge as a source of problem solving; with the evolution of industry in the eighteenth century, innovation finally gained autonomy and ceased to be associated with the activity of execution (Zawislak, 1995). In this study, as explained in its introductory section, in conceptual terms, the innovation process is assumed as a continuous cycle of construction and incorporation of knowledge, and involves the search, selection and implementation of ideas, in a constant progression of learning (Tidd, Bessant \& Pavitt, 2008).

\subsection{INNOVATION PROCESS}

The concept of innovation process corresponds to a central process within the organization and is summarized in the construction and incorporation of the following elements: search, selection, implementation and learning (Tidd, Bessant \& Pavitt, 2008). In order for the process of innovation in organizations to occur, certain requirements must be studied: innovation strategy, a structure that enables the innovative process, organizational context for facilitating innovation and the realization and maintenance of lasting partnerships (Tidd, Bessant \& Pavitt, 2008), which implies considering, besides, the creativity or capacity to generate new ideas (Shavinina \& Seeratan, 2003), also intra and interorganizational communication and external economic conditions (Costa Souza \& Bruno-Faria, 2013). 
For Anjo, Barbosa, Bouzada \& Neto (2012), innovation is essentially identifying opportunities that others do not see or do not realize their real potential. In this sense, it can be said that the strategy of innovating is equivalent to the choice to compete through innovation. The type of innovation strategy selected (organizational, process, marketing, product and service), determines the choices in terms of partnerships, design and organizational culture, in addition to communication systems and forms of intra and interorganizational interaction (Gonzalez, 2014). In this research, I assume that the concept of innovation is associated with that of organizational learning (Nonaka \& Takeuchi, 1997; Stewart, 1998; Ayas, 1999; Senge, 2000; Kaplan \& Norton, 2000; OCDE, 2005; Leite, Seidl \& Antunes, 2008; Isidro Filho \& Guimarães, 2010; Salim \& Sulaiman, 2011; Fleury \& Fleury, 2011; Caldeira \& Godoy, 2012; Vilha, 2013; Gonzalez \& Campos, 2015), and that learning promotes new ideas that when reproduced on a significant and reliable scale are innovations capable of promoting transformations (Senge, 2000).

Therefore, learning and innovation are integrated, interdependent and learning must be managed proactively, in order to provide the necessary integration for the emergence of innovation (Gonzalez \& Campos, 2015), from a triple cycle of learning that is equivalent to the process of learning to learn, and requires collective reflection on the basic assumptions and rules established in the organization (Argyris \& Schön, 1978).

As already mentioned, innovation management must be able to manage or do better what is already known and done, but in a different way (Tidd, Bessant \& Pavitt, 2008). The achievement of desired change in terms of innovation implies considering the culture of seeking meaningful learning in the organizational environment, which corresponds to that learning that starts from the existing knowledge in the subject and, from it, I work on the search for new knowledge (Ausubel, 1968). In essence, innovation is a process in which ideas are generated that can lead to the creation of knowledge and, therefore, every innovation project has the potential to learn (Ayas, 1999).

Therefore, this study assumes the importance of seeking to know, in addition to the innovation process, also the learning process, since the organizations that excel by innovations from learning processes, tend to be more able to survive; and innovation in this context is more than simply designing a new idea, it is a process of developing its practical use (Tidd, Bessant \& Pavitt, 2008).In essence, innovation is a process in which ideas are generated, which can lead to the creation of knowledge and, the development and application of knowledge forming knowledge (Antonello, 2005).

\subsection{LEARNING PROCESS AS THE START FOR INNOVATIONS}

The process of organizational learning involves both the elaboration of new cognitive maps that make possible a better understanding about what is happening in its internal and external environment, as well as the definition of new behaviors that prove the effectiveness of learning (Fleury \& Fleury, 2011).In addition, the learning process must have a systemic character and not only focus on a unit or department of the company, but it must go beyond the company's doors, from the interactions with the stakeholders (Senge, 2000; Fleury \& Fleury; 2011).

In addition to interactions with stakeholders, to achieve this learning, it is necessary to observe and manage periods of instability and stability or irregularity and regularity in the environments (a boost from dynamic capabilities) (Prahalad \& Hamel, 1990).Therefore, for the emergence of innovation, I surmised, in this study, the assumption that innovation takes place through a progressive, artisanal process, with continuous interaction of the company's capabilities: organizational learning and innovation management. Moreover, that the interaction of these capabilities must also occur with the external environment, in a continuous flow, facilitated by mid-level managers, in the cases of medium and large companies, and by entrepreneurs, in small enterprises (Gonzalez \& Campos, 2015). 
Teece, Pisano and Shuen (1997) explain that the term capacity refers to the role of management in adapting, integrating and appropriately reconfiguring organizational, internal and external skills, resources and competencies so that it is possible to adapt the organization to the highly changeable environment. The approach to the dynamic capabilities by Prahalad and Hamel (1998) emphasizes its development essentially through a strategic learning process, in which the strategy is seen from inside to outside the organization, from an emphasis on the capacity that the organization has to learn. In the discussion related to strategic learning that, according to Prahalad and Hamel (1990) combine reflection with result, it is also important to reflect on certain concepts and questions linked to the learning process itself (Table 1).

\begin{tabular}{|c|c|c|}
\hline It is needed & How? & It is necessary to reflect on: \\
\hline $\begin{array}{l}\text { - Learning the } \\
\text { discipline of per- } \\
\text { sonal mastery }\end{array}$ & $\begin{array}{l}\text { Through the search for an experience in } \\
\text { which a high level of proficiency is desired, } \\
\text { and people commit to pursuing their own } \\
\text { learning over time. }\end{array}$ & $\begin{array}{l}\text { What is really important to me? Do I live in } \\
\text { the service of my highest aspirations? }\end{array}$ \\
\hline $\begin{array}{l}\text { - Learning the } \\
\text { discipline of } \\
\text { mental models } \\
\text { (MM). }\end{array}$ & $\begin{array}{c}\text { Turn the mirror inside, learn to dig up the } \\
\text { inner images of the world to bring them to } \\
\text { the surface and keep them under rigorous } \\
\text { analysis. }\end{array}$ & $\begin{array}{c}\text { Am I aware of my MM (images, ingrained } \\
\text { assumptions, generalizations)? Does my } \\
\text { way of seeing and acting in the world come } \\
\text { from my level of consciousness about my } \\
\text { beliefs, by rigorous analysis? }\end{array}$ \\
\hline $\begin{array}{l}\text { - Learn the dis- } \\
\text { cipline of shared } \\
\text { vision }\end{array}$ & $\begin{array}{l}\text { It must be understood that the leader is not } \\
\text { the one who dictates or imposes the path } \\
\text { to action, but those who seek participation, } \\
\text { interaction and involvement of the people } \\
\text { until reaching the desired mission. }\end{array}$ & $\begin{array}{l}\text { In what way do I talk? How do people talk? } \\
\text { Is there a quest to develop images of the } \\
\text { future through dialogue (flow of meaning) } \\
\text { between these people? }\end{array}$ \\
\hline $\begin{array}{l}\text { - Learning the } \\
\text { discipline of } \\
\text { team learning } \\
(\mathrm{TL}) \text {. }\end{array}$ & $\begin{array}{c}\text { It is necessary to learn that dialogue leads } \\
\text { to interaction, and that interaction leads } \\
\text { to thinking together, shared vision and the } \\
\text { consequent TL }\end{array}$ & $\begin{array}{c}\text { Do I put aside my preconceived ideas and } \\
\text { participate in a true thinking together? Do } \\
\text { I recognize the interaction patterns that } \\
\text { make TL difficult? }\end{array}$ \\
\hline $\begin{array}{l}\text { - Learning the } \\
\text { discipline of sys- } \\
\text { temic thinking } \\
\text { (ST) }\end{array}$ & $\begin{array}{l}\text { It is necessary to learn that the ST leads to } \\
\text { the clarification of the established standards } \\
\text { and the ability to modify this standard. That } \\
\text { if one learns this discipline, one arrives at } \\
\text { the integration of the people. }\end{array}$ & $\begin{array}{l}\text { Do I have the ability to see the most impor- } \\
\text { tant interrelations that are able to influen- } \\
\text { ce behavior over time? }\end{array}$ \\
\hline
\end{tabular}

Table 1: The learning disciplines and the associated questions.

Source: Adapted from Senge (2000). Note: Elaborated by the author.

At the moment when I seek to reflect on how it is possible to conquer this managerial capability to adapt, integrate and reconfigure skills, it also raises the question of what needs to be learned so that the role of the competitive strategy to innovate is achieved. In this regard, Senge (2000) argues that it is necessary to learn the discipline of systemic thinking, because companies lack a discipline capable of translating individual vision into a shared vision. In addition, for the innovation process to happen, it is also necessary to believe that even what is good can be improved, in which people are able to question what they continually know (Gramigna, 2004).

In the present study, I stress that the ability of companies to achieve superior results depends on the ability of managers to coordinate and manage tangible and intangible resources, aiming at the improvement and continuous refinement of its processes (Teece, Pisano \& Shuen, 1997). For to the extent that the information age requires employees who can add value to the knowledge they possess and the information they can provide, the mobilization capacity of intangible assets has become far more decisive than investing and managing tangible physical assets (Kaplan \& Norton, 2000).

Based on this context, I assumed in this research the need for the organizational culture to be focused on the policy of learning to learn, which requires collective reflection; and that to occur to 
continuous learning there must be continuous improvement that involves all, including managers and other employees, from the practice of questioning what is known continuously (Fleury \& Fleury, 2011).

Throughout the management of the innovation process, so that those pursued and shared goals can be fully met, some characteristics in the organizational environment need to be developed, taking into account the alignment between the innovation processes and the learning processes, with the competitive strategy. These characteristics are: management commitment, flexible organizational design to facilitate interactions between people of all hierarchical levels, with open communication systems to achieve uniqueness of direction; organizational culture focused on constant learning and the search for information in the competitive environment (Gonzalez \& Campos, 2015).

According to Vilha (2013), the analysis of the external environment is relevant throughout the process of strategy formation, given that there is an era of uncertainty and rapid changes in agents and markets. Faced with the intense pace of new products, processes and services, organizations that can innovate can create lasting advantages over their competitors (Costa Souza \& Bruno-Faria, 2013). Thus, the dynamics of the environment and the speed of information require companies to continuously monitor the external environment, in particular those that seek to innovate from the culture of learning to learn (Gonzalez \& Campos, 2015).For this reason, it becomes a determining factor in the innovation process, the reflection about the necessary conditions in the organizational environment, in order to promote a culture of continuous learning, with a view to the emergence of innovation.

In the internal environment and in the interaction with partners that are strategic for the company, management plays a fundamental role in the process of learning and transfer of knowledge, in that it is responsible for coordinating and integrating the efforts of the teams for a given focus that is strategic for the organization. However, the theory intended to explain how managers transform resources is minimal (Sirmon, Hitt \& Ireland, 2007). The Resource-Based View Theory - RBV claims, for example, that the resources developed and controlled by the company are the main source of competitive advantage when they prove valuable, rare, inimitable and irreplaceable (Barney, 2001). The dynamic capabilities approach (skills in reaching new sources of competitive advantage) considers that in a turbulent environment, competitive advantages are not sustainable and the superior performance stems from the sum of temporary advantages that are created continuously (Eisenhard \& Martin, 2000).Therefore, it is relevant to reflect on the challenges related to the innovation process and, the way management manages them in order to respond to the competitive and dynamic environment.

\subsection{CHALLENGES RELATED TO THE INNOVATION PROCESS}

The real challenge of innovation is not invention, but to make technical and commercial work on inventions or the raising of new ideas (Tidd, Bessant \& Pavitt, 2008). It is for this reason that every company needs to find its own way of doing things, to develop their own specific routines. However, effective innovation management routines are not easily obtained because they represent what the company has learned over time, by means of a process of mistakes and successes (Tidd, Bessant \& Pavitt, 2008).

Considering that innovation represents a process of implementation of new ideas and practices, in a social context affected by environmental conditions that assumes collective interactions (Marinova \& Phillimore, 2003) and a continuous cycle of building and incorporating knowledge, in a constant progression of learning (Tidd, Bessant \& Pavitt, 2008), the study about the organizational context that facilitates the emergence of innovation (Table 2 ) becomes key to addressing the challenges of the innovation process. 
From the innovation requirements based on learning, I can reflect on the impetus of the capabilities needed for the innovation process to take place and, in a more effective way. Table 2 reinforces the need for management to develop spaces for interactions, aiming the exchange of knowledge and learning, with the aim of conquering the culture of continuous improvement, necessary for the innovations (Gonzalez, 2014). Organizational learning results in the organization's core competencies, especially in the coordination of the various production skills and in the integration of multiple technologies, that is, different means by which a company transforms inputs into results (Prahalad \& Hamel, 1990).

It is worth remembering that individual learning is a mental cognitive process, and organizational learning is a social process (Lipshitz, Friedman \& Popper, 2007) that moves with the interaction of the individual learning and the teams, since, for the organization to learn, it has to create an environment that facilitates the development of learning, with culture, values, vision, policies and routines sensitive to the change and the interaction of its collaborators (Gonzalez, 2014).

In addition, in order to make systemic thinking active and daily, it is important to consider the management of the innovation process, that well-focused attitudes can produce significant and lasting improvements (Gonzalez, 2014). One cannot continue the learning and innovation located only in the production system as it used to in the industrial era, because the management of an organization that learns and innovates must have systemic vision, and both the use, as well as knowledge development, should be linked to the competitive strategy (Fleury \& Fleury, 2011).

\begin{tabular}{|c|c|c|c|c|}
\hline \multicolumn{3}{|c|}{ INNOVATION REQUIREMENTS } & \multirow{2}{*}{$\begin{array}{l}\text { Until you reach } \\
\text { Innovation: }\end{array}$} & \multirow[t]{2}{*}{ Adapted from Author(s) } \\
\hline Learning to (or) & To get to (at) & Aiming at (o) & & \\
\hline Use Concepts & $\begin{array}{c}\text { Know how to apply } \\
\text { them }\end{array}$ & Individual learning & Incremental & $\begin{array}{c}\text { Senge (2000); Be- } \\
\text { thlem(2001); Tidd, Bes- } \\
\text { sant and Pavitt (2008) }\end{array}$ \\
\hline Dialogue & Interaction & Individual Learning & Incremental & $\begin{array}{l}\text { Senge(2000);Tidd, Bes- } \\
\text { sant and Pavitt (2008) }\end{array}$ \\
\hline Interact & $\begin{array}{c}\text { Organizational Lear- } \\
\text { ning }\end{array}$ & $\begin{array}{l}\text { Behavior change, } \\
\text { from the dynamic } \\
\text { process generated } \\
\text { by organizational } \\
\text { learning }\end{array}$ & $\begin{array}{l}\text { of Product } \\
\text { of Process } \\
\text { of Organizatio- } \\
\text { nal Marketing }\end{array}$ & $\begin{array}{c}\text { Fleury and Fleury(2011); } \\
\text { Cruzan, Lane and White } \\
\text { (1999); OCDE (2005). }\end{array}$ \\
\hline Learn & $\begin{array}{l}\text { Continuous Improve- } \\
\text { ment }\end{array}$ & Adaptation & $\begin{array}{l}\text { Incremental } \\
\text { and/or radical }\end{array}$ & $\begin{array}{l}\text { Fleury and Fleury (1995); } \\
\text { Tidd, Bessant and Pavitt } \\
\text { (2008). }\end{array}$ \\
\hline Systemic Learning & $\begin{array}{c}\text { Integration of people } \\
\text { (essential skills) and } \\
\text { Technology Integra- } \\
\text { tion }\end{array}$ & $\begin{array}{l}\text { Continuing Learning } \\
\text { Culture }\end{array}$ & $\begin{array}{l}\text { of Product } \\
\text { of Process } \\
\text { of Organizatio- } \\
\text { nal Marketing }\end{array}$ & $\begin{array}{c}\text { Senge (2000); OCDE } \\
\text { (2005); Fleury and Fleury } \\
\text { (2011); Prahalad and Ha- } \\
\text { mel (1990). }\end{array}$ \\
\hline $\begin{array}{c}\text { Question what } \\
\text { is known conti- } \\
\text { nuously }\end{array}$ & $\begin{array}{l}\text { New beliefs, values } \\
\text { and principles }\end{array}$ & $\begin{array}{l}\text { Culture of Learning } \\
\text { to Learn, of inno- } \\
\text { vation, and conse- } \\
\text { quently of conti- } \\
\text { nuous adaptation }\end{array}$ & $\begin{array}{l}\text { of Product } \\
\text { of Process } \\
\text { of Organizatio- } \\
\text { nal Marketing }\end{array}$ & $\begin{array}{c}\text { Fleury and Fleury (2011); } \\
\text { Senge (2000) and Tidd, } \\
\text { Bessant and Pavitt } \\
\text { (2008). }\end{array}$ \\
\hline $\begin{array}{c}\text { Managing innova- } \\
\text { tion in a systemic } \\
\text { way }\end{array}$ & $\begin{array}{l}\text { The disciplines: per- } \\
\text { sonal domain, mental } \\
\text { models, shared vision, } \\
\text { teamwork, systemic } \\
\text { thinking. }\end{array}$ & $\begin{array}{l}\text { Continuous adap- } \\
\text { tation; } \\
\text { Competitive advan- } \\
\text { tage }\end{array}$ & $\begin{array}{l}\text { In the forma- } \\
\text { tion of new } \\
\text { strategies }\end{array}$ & $\begin{array}{c}\text { Senge (1998); Kaplan and } \\
\text { Norton (2009). }\end{array}$ \\
\hline
\end{tabular}

Table 2: Innovation requirements based on learning.

Source: Gonzalez (2014). 
In this sense, Table 3 shows the contents necessary for the management of the innovation process, this depends on being aligned with the competitive strategy.

\begin{tabular}{|c|c|c|c|c|c|}
\hline Detailing & $\begin{array}{l}\text { 1st Mission, } \\
\text { Values and Vi- } \\
\text { sion (MVV) }\end{array}$ & $\begin{array}{l}\text { 2ndAnalysis of } \\
\text { the External } \\
\text { Environment } \\
\text { (AE) }\end{array}$ & $\begin{array}{l}\text { 3rdOrganizational } \\
\text { Learning }(O L)\end{array}$ & $\begin{array}{l}4^{\text {th }} \text { Innovation } \\
\text { management } \\
\text { (IM) }\end{array}$ & $\begin{array}{c}\text { 5th }(\mathrm{AE}) \text {-Strate- } \\
\text { gy Alignment }\end{array}$ \\
\hline $\begin{array}{l}\text { Descrip- } \\
\text { tion }\end{array}$ & $\begin{array}{l}\text { Knowledge of } \\
\text { the strategic } \\
\text { direction of the } \\
\text { company }\end{array}$ & $\begin{array}{l}\text { Exploratory } \\
\text { stage of the } \\
\text { environment in } \\
\text { which the com- } \\
\text { pany enters }\end{array}$ & $\begin{array}{c}\text { Exploratory stage of } \\
\text { the company's stren- } \\
\text { gths and weaknesses } \\
\text { in organizational } \\
\text { learning }\end{array}$ & $\begin{array}{c}\text { Exploratory stage } \\
\text { of the company's } \\
\text { strengths and we- } \\
\text { aknesses in rela- } \\
\text { tion to innovation } \\
\text { management }\end{array}$ & $\begin{array}{l}\text { Alignment of pre- } \\
\text { vious stages }\end{array}$ \\
\hline $\begin{array}{l}\text { Objective } \\
\text { (s) }\end{array}$ & $\begin{array}{l}\text { Share the mis- } \\
\text { sion, values and } \\
\text { vision of the } \\
\text { company with } \\
\text { all employees }\end{array}$ & $\begin{array}{l}\text { Identify oppor- } \\
\text { tunities and } \\
\text { threats that } \\
\text { determine com- } \\
\text { pany action }\end{array}$ & $\begin{array}{c}\text { Identify enterprise } \\
\text { capabilities in rela- } \\
\text { tion to organizational } \\
\text { learning } \\
\text { Direct learning for in- } \\
\text { novation capacity }\end{array}$ & $\begin{array}{l}\text { To adapt the } \\
\text { capacity of in- } \\
\text { novation to the } \\
\text { demands of the } \\
\text { environment in } \\
\text { which the com- } \\
\text { pany is inserted }\end{array}$ & $\begin{array}{l}\text { Form business } \\
\text { strategies based } \\
\text { on the integration } \\
\text { of organizational } \\
\text { learning and in- } \\
\text { novation mana- } \\
\text { gement }\end{array}$ \\
\hline $\begin{array}{l}\text { Way of } \\
\text { perfor- } \\
\text { ming }\end{array}$ & $\begin{array}{c}\text { Formal and in- } \\
\text { formal commu- } \\
\text { nication } \\
\text { Regular mee- } \\
\text { tings } \\
\text { Events }\end{array}$ & $\begin{array}{c}\text { Research } \\
\text { Reviews } \\
\text { Brainstorming } \\
\text { between mana- } \\
\text { gers and colla- } \\
\text { borators }\end{array}$ & $\begin{array}{l}\text { Training Programs } \\
\text { Regular meetings } \\
\text { Adjusting layout for } \\
\text { learning exchanges } \\
\text { Incorporate the } \\
\text { product of everyday } \\
\text { learning } \\
\text { Give time for lear- } \\
\text { ning }\end{array}$ & $\begin{array}{l}\text { System of stimu- } \\
\text { lation and reward } \\
\text { for ideas and cre- } \\
\text { ativity. Problem } \\
\text { solving in groups; } \\
\text { Brainstorming; } \\
\text { Putting employe- } \\
\text { es' creative ideas } \\
\text { into practice } \\
\text { Create chat spa- } \\
\text { ces between } \\
\text { collaborators/ } \\
\text { managers. }\end{array}$ & $\begin{array}{l}\text { Survey of essen- } \\
\text { tial information } \\
\text { from previous } \\
\text { stages } \\
\text { The sum of the } \\
\text { previous stages } \\
\text { results in the } \\
\text { choice of the best } \\
\text { strategic action } \\
\text { Describe strategy } \\
\text { in detail }\end{array}$ \\
\hline Product & $\begin{array}{l}\text { Understanding, } \\
\text { uniqueness and } \\
\text { commitment to } \\
\text { company mis- } \\
\text { sion, values and } \\
\text { vision }\end{array}$ & $\begin{array}{l}\text { Understanding } \\
\text { of the environ- } \\
\text { ment in which } \\
\text { the company is } \\
\text { inserted }\end{array}$ & $\begin{array}{l}\text { Creation of a lear- } \\
\text { ning culture that } \\
\text { favors the develo- } \\
\text { pment of Senge's } \\
5 \text { disciplines and } \\
\text { contributes to inno- } \\
\text { vation }\end{array}$ & $\begin{array}{c}\text { Formation of a } \\
\text { culture of innova- } \\
\text { tion in everyday } \\
\text { practice } \\
\text { Innovations } \\
\text { aligned with the } \\
\text { environment and } \\
\text { integrated with } \\
\text { the company's } \\
\text { competences }\end{array}$ & $\begin{array}{l}\text { Formation of } \\
\text { good strategies } \\
\text { for positioning } \\
\text { the company in } \\
\text { the environment; } \\
\text { Strategies that } \\
\text { generate value }\end{array}$ \\
\hline $\begin{array}{l}\text { Characte- } \\
\text { ristics }\end{array}$ & $\begin{array}{c}\text { + Flexible or- } \\
\text { ganizational } \\
\text { design } \\
+ \text { Interaction } \\
\text { among em- } \\
\text { ployees at all } \\
\text { levels } \\
\text { + Open commu- } \\
\text { nication sys- } \\
\text { tems }\end{array}$ & $\begin{array}{l}\text { Stage } 1 \text {-Greater } \\
\text { interaction with } \\
\text { suppliers and } \\
\text { customers; Cus- } \\
\text { tomer-centered } \\
\text { organizational } \\
\text { culture; Strate- } \\
\text { gic partnering } \\
\text { with suppliers }\end{array}$ & $\begin{array}{c}\text { Stage } 1 \text { to } 2 \\
\text { Training Programs } \\
\text { + Leadership Com- } \\
\text { mitment } \\
\text { Time for employees } \\
\text { to devote themsel- } \\
\text { ves to learning }\end{array}$ & $\begin{array}{c}\text { Stage } 1 \text { to } 3 \\
\text { Structure that } \\
\text { enables innova- } \\
\text { tions Culture of } \\
\text { incentive to new } \\
\text { ideas and crea- } \\
\text { tivity } \\
\text { Long-lasting part- } \\
\text { nerships }\end{array}$ & $\begin{array}{c}\text { Stage } 1 \text { to } 3 \\
\text { Mid-level mana- } \\
\text { gement orienta- } \\
\text { tion in the choice } \\
\text { and strategy for- } \\
\text { mation }\end{array}$ \\
\hline
\end{tabular}

+ Characteristic common to all steps

Table 3: Proposed matrix on the Integration between Organizational Learning and Innovation Management in the Competitive Strategy.

Source: Gonzalez (2014). 
From the alignment between the innovation process, the MVV and the competitive strategy (Table 3), I set out to (re)read the external environment, since the external sources of information show the position of the organization's competitors, partners and clients, providing insights for the creation of innovation and development of organizational learning.

Learning occurs at the individual and collective level, at the operational and managerial level, stimulating creativity and generating innovation in terms of products, processes, marketing and organizational. The innovation process provokes new learning, forming with the interaction of these organizational capabilities (innovation and learning), the business strategy. In this interactive process, new strategies are created and learning and innovations emerge in the organization in a perspective that takes into account the dynamics of the environment, the sharing of knowledge, valuing the integration of people from all levels of the organization (Gonzalez, 2014). The processes of formulation and implementation are transformed into a continuous process of learning through which creative strategies emerge (Mintzberg, 1987).

In this article, I sought to reflect on the challenges related to the innovation process in the industrial companies investigated, exploring the themes and reasoning exposed in the matrix (Table 3 ), supported by the conceptual relations related to the literature of competitive strategy, innovation management and organizational learning.

\section{METHODOLOGICAL ASPECTS OF RESEARCH}

The present research uses a combination of methods: theoretical-conceptual, bibliographical survey and the multi-case study. The theoretical-conceptual method represents a study on the bibliographic reference, between several authors who write on the subject (Berto \& Nanako, 1998), and aims to deepen the analysis of the object of study (Miguel, 2007). The bibliographic survey method was conducted based on the steps proposed by Marconi and Lakatos (2003): identification, location, obtaining and registration that is equivalent to records of the bibliographic sources; and the multi-case method is a thorough and exhaustive study, in order to obtain its ample and detailed knowledge (Gil, 2002).This study aimed to explore the innovation process of cosmetic companies, by means of the following procedures: semi-structured interview, observation route and document analysis, in order to be possible, on the basis of the theoretical basis, reveal reflections on the way that the managers of these companies deal with the challenges of the innovation process.

The approach of the proposed problem occurred qualitatively, in which the subjective reality of the individuals involved is relevant and the interest is not in the results, but in how I came to them (Miguel, 2010). In addition, it has exploratory character, in which it was sought to explore and provide greater familiarity with the problem, with a view to making it explicit (Gil, 2002; Turrioni \& Mello, 2012; Miguel, 2010). Exploratory research occurs in fields in which there is little accumulated and systematized knowledge (Vergara, 2011).Thus, from the point of view of its objectives, because it is exploratory, this research sought to provide greater familiarity with the problem investigated and make it explicit from the application of semi-structured interview (Gil, 2002) together with managers of cosmetic companies focused on the management of the innovation process.

I applied the semi-structured interview with a script containing open questions that underwent a pilot test with four specialists with experience in the industrial sector and/or who study the challenges related to the industry. From the return of these experts, I added a question about the relationship of companies with their clients. After reviewing the instrument and already having the consent of the research participants who were previously informed of the study objectives, I followed the interview, respecting the privacy of managers and companies. I also used the technique of direct 
observation and analysis of documents. The information analyzed in the documents were: training policies and people development; forms of communication and interaction between the different hierarchical levels; types of technologies capable of integrating communications and/or leveraging individual knowledge; history of innovations and performance reports. "This multiplicity of sources of evidence is vital for the reliability of the data collected, because the different sources reinforce themselves or not, thus increasing the internal validity of the research" (Miguel, 2010, p. 52).

Through an itinerary of observation, I sought to observe the forms of work organization (individual and organizational) and communication (formal and informal); types of layouts, information systems (notices, tables, panels) and technologies (machines, equipment and software). The visit to the large company was not possible due to the schedule of the company and the manager; therefore, I obtained all this information through telephone contact and e-mail. To achieve this research, I followed the guidelines by Bardin (1977), in which the material was first selected (data and information collected). Next, I carried out the exploration of this material and the identification of the analysis themes that I explored in the questions of the semi-structured interview and extracted from the assumptions that support the contents of Table 3 of the theoretical framework. Finally, I start with the treatment of data and interpretation, the stage at which the inferences and the results are generated (Bardin, 1977).

The content analysis used aims at understanding the game environment at a given moment and is a technique that (Bardin, 1977, p. 38), "[...]seeks to know what lies behind the words on which one dwells", which makes it possible to see the importance of the criteria adopted for the choice of research participants. The people interviewed should be those who are directly linked to the focus of analysis or who are able to provide information about it (Bardin, 1977). In the case of this study, three managers, with one being responsible for the coordination of human resources processes and a member of the body of owners of small businesses; the other an owner and responsible for all the final choices of decision-making processes in the medium-sized company, including the innovation processes; and, the manager of the network of innovations of the company of large cosmetics. During the collection of the information, I followed the script of the interview questions and whenever possible, I explored the meaning given by each manager to the activities of the company related or not to the emergence of new ideas, to the forms of interaction and communication between employees for the emergence of new knowledge and learning. The interviews, in the case of small and medium-sized companies, were recorded and transcribed. In the case of the large company, the responses were all provided by e-mail, with some telephone contacts. Even so, there were no problems to get the data on the large company.

The following topic points out the challenges related to the innovation process in the three companies studied: one located in the city of Serra-ES (small size, with 26 employees), another in Vila Velha-ES (medium-sized, with 40 employees) and the one that is located in the State of São Paulo (large, with 7,000 employees). In this article, these companies are identified, respectively, as: EPP, EMP and EGP. EPP was founded in 2004, EMP in 1998 and EGP in 1969. EPP and EMP are from the industrial sector of cosmetic products; EGP, of the industrial sector of personal hygiene, perfumery and cosmetics. In terms of number of products, respectively: EPP has 250 items, EMP 126 items, and EGP more than 1000 items. 


\section{MULTI-CASE STUDY WITH COSMETIC INDUSTRIES - REFLECTIONS ON THE CHALLENGES OF THE INNOVA- TION PROCESS}

Reflections on the innovation process challenges outlined below, were based on analysis and interpretation, the relationship between the process of forming a competitive strategy and the development of the organization's capabilities (organizational learning and innovation management). The innovation process is assumed to be an interrelated process with the organizational learning process and both to the process of forming the competitive strategy. In other words, it is assumed that organizational processes of learning and innovation must be aligned with business strategy, and that they are interrelated. Consequently, the challenges of the innovation process correspond to the absence of the interrelationship between the learning processes and the process of innovations, product / service, process, marketing or organizational innovations. This interrelationship implies the effective attainment of the objectives present in the matrix (Table 3). Thus, in order to meet the challenges inherent in the innovation process in the three cosmetic companies, I grounded it on learning-based innovation requirements (Table 2) and the stages, objectives and interrelationships of matrix contents (Table 3).

\subsection{THE MANAGEMENT OF CHALLENGES IN THE SMALL BUSINESS}

Based on the assumption that the oneness and commitment of all with the mission, vision and values - MVV can drive organizational behavior to achieve planned performance; and, that employees at all levels of the organization must become aware of the business, as well as the philosophy and peculiarities that the company values and defends, is that analyzes were made on how the institutional direction is given in cosmetic companies, focused on innovation, followed by the contents of Table 3. It is worth stressing that in each company I seek to identify and analyze the challenges experienced and the way they were managed in the innovation process.

During the analysis of the information collected in the small business-EPP, I noted that there is high interaction between the general manager and the operational level, but more related to the verification of what is happening in terms of internal efficiency and less focused on the search for new ideas and knowledge and the sharing of MVV.

About the challenges associated with the goal of sharing MVV with all company employees, I came to the realization that they are more related in EPP, with the short time spent by management and the board in focusing on the transmission of the company's strategic direction to employees, in a flow of knowledge exchange.

Through the visit and the interview with the manager, I have obtained that the CEO is responsible for generating any change in EPP, both from their knowledge and experience, as well as from their interactions with any supplier or distributor. It is the CEO who creates and exposes the greatest number of ideas, tests and redefines products and processes. Although the EPP manager sees the importance of looking for incremental and/or radical innovations in activities aimed at the emergence of innovations, he does not spend time in the process of forming an organizational culture focused on interactions in this sense; there are also no routines linked to the proactive development of employees in the quest to think the MVV, only the strong idea that the CEO is the most creative person and who should continue to make decisions about the MVV.

From the routines identified in EPP, I was able to verify that the intra-organizational interaction on the MVV goes from low to moderate, because there is no practice of periodic meetings, only 
sporadic to create new products/services, processes or new organizational practices. The discussion of problems and projects is only made between the managers and the senior director without taking advantage of the individual competences of the other departments. There is a strong focus on production and there are no rooms or spaces for interactions aimed the exchange of ideas and search for new solutions involving management and operational level. The communications system is predominantly informal, from the problems that arise in everyday life. The formal structure of EPP is hierarchical. The lines of communication follow the command lines and, the flows are more vertical, that is, between the different levels, but of the same area of performance.

In the case of diagonal communication lines between units and different levels, they happen, but more so, at the initiative of the CEO who attends all areas of the company in day-to-day routines. The horizontal flows, between different units, but of the same hierarchical level, happen to a lesser extent with regard to the exchange of ideas. Only from a particular year onwards was it evidenced by the manager as there being more interaction, because the CEO is always ahead of everything and it is whom decides the pace and tone of the communications about what should be changed, improved, improved or transformed.

Another assumption assumed in this study is that to create or form a competitive business strategy that refers to the innovation strategy, the company should seek information about the market, competition, suppliers and customers; identifying opportunities and threats that may affect the strategy and devote efforts to align their internal capabilities. Therefore, it is in a process of continuous interaction between environment, organizational learning and innovation management that the innovation strategy and/or innovations must form. In this respect, it was noticed that the understanding of the environment in which EPP is inserted, occurs from the sellers; interaction with the managers and the general manager on new information from the external environment depends, for example, on the needs of the customers and the changes in the products of the competitors. Through the interview, I learned that in EPP, the use of the database of its clients to obtain and study information and from them to discuss new ideas is not done. The database is used solely to control the types and frequencies of applications. Information about possible suggestions, likes, interests and complaints is not even used to make adaptations.

About the challenges associated with the goal of exploring the environment in which the company operates, in order to generate opportunities for the emergence of learning and innovations, were observed in the EPP: lack of planning and monitoring of information from the external environment and lack of projects aiming at a rapprochement with clients. The EPP routines confirm that there is low adherence of the company to the necessary requirements to be able to identify opportunities and threats that determine the action of the company: communication systems that, although open, are not focused on the strategic direction and still, lack of exchange of information with a view to monitoring the external environment in a participatory manner.

In addition, inter-organizational interaction with suppliers and customers is more focused on efficiency, agility of delivery and in control over bureaucratic processes than in reading the market needs for the creation of changes or innovations. The organizational culture is focused on the quality, efficiency, brand reputation and product reliability, but it is not focused on collective learning for the emergence of innovations.

Based on the foregoing, I understand that in EPP, there is no creation of a strategic consciousness in the broad sense, as stated in the matrix (Table 3), nor management that operates effectively in the environment where the EPP is inserted. Consequently, what was seen in terms of organizational learning, innovation management and strategy alignment, it was a low adherence of the EPP, because although there is time for the employees to dedicate themselves to learning in the 
trainings, these aim at individual learning only; and although there is commitment of the leadership by the CEO, there is lack of direction for actions involving other stakeholders in the search for new knowledge. Although there are long-term partners between EPP and its distributors, there is a low flexibility of the structure that enables innovations and a culture with low incentive for new ideas. Finally, I verified that there is strong centralization by the management of the EPP, which facilitates accommodation and non-proactive behavior on the part of the other employees in the innovation process, which happens very dependent on the image of the owner, CEO of the company.

\subsection{THE MANAGEMENT OF CHALLENGES IN THE MEDIUM SIZED COMPANY}

From the analysis regarding the institutional direction made in the cosmetic company of medium-size - EMP I seek to study the way in which the process of sharing mission, vision and values is carried out- MVV. Since 2010, at EMP, the practice of sharing MVV with strategic business planning at periodic meetings involving management and operations professionals, and at times when a new employee arrives to work, when they become aware of the company's internal regulations, including rules of conduct.

During the interview, the manager of EMP emphasized the importance that is given by its professionals to follow continuously in the reach of the MVV, including their distributors should also know and contribute so that the business can be seen as serious, seeking excellence; the values are shared also in the Internal Week of Accident Prevention (SIPAT), in the quarterly meetings and company celebrations.

Because EMP is undergoing an implementation process in terms of increasing the physical space of operations, I sought to know how the manager deals with the balance between complying with what was planned for the period, while at the same time building plans for the future focused on more innovative practices. Moreover, considering that, the forms of communication can facilitate or not the process of new ideas and exchanges of knowledge, I seek to analyze the way the manager seeks to build the practice of reflecting on what can be exploited in terms of new content by employees. The EMP manager stated that she is "[...] still somewhat conservative [...]"in the sense of being highly concerned "[...] in not losing focus [...]"; that managers have spaces and opportunities for communications, discussions and interactions, but there is also a certain delay in the decision-making process in terms of the choice of new ideas, insofar as"[...] great care is taken in reviewing and complying". There is concern in listening to the team and reinforcing in the company's day-to-day culture that "one department is customer of the other", and therefore, "[...] communication is considered key in the day to day, in the routines of the company".

In order for communications between the EMP departments and between EMP and its stakeholders can be carried out more effectively, there is a professional programmer who develops with EMP's own employees, discussions about how to better exploit system's data, Enterprise Resource Planning (ERP) used by the company, especially on customers. The contracting of the services of this programmer occurred from a project, still under development, for the team to learn how to deal with the ERP and to explore their data in daily routines; the challenge is to get this system to provide, for example, the number of beauty salons per region and the quantity of products sold per salon.

Another process, described by the manager during the interview and aimed at integrating stakeholders, enhancing relationships with beauty salons, and building lasting partnerships with hairdressers, was to build a beauty kit with the participation of hairdressers, where they had to respond to a questionnaire after using the products. The construct was developed through the sugges- 
tions collected in the questionnaires, and then, the EMP manager held an event with her team at the convention center, in which the hairdressers were invited to participate in the draws of various gifts and to approach the creation process of the industry. It can be concluded that EMP is focused on an innovation process based on interaction with stakeholders, valuing the knowledge and learning of those who use and disseminate the products to the final consumers, that is, the hairdressers, while keeping the spirit of collaboration in the partnership close.

Within the EMP, the culture of monitoring, recording and discussing the information coming from customers through telephone calls made by them to EMP, on a form built by the team, in order to monitor their satisfaction. The form is next to the telephone handsets and each call in which the subject is praise, criticism or suggestion is recorded for further discussion at a meeting so that solutions are discussed. This process connected to the communication between the company's customers and employees and between employees and the management, in meetings, appeared to be a familiar and habitual habit in the daily life of EMP; simple to capture and track customer satisfaction. The challenge is to get to know the ways of loyalty of distributors who work with beauty salons, especially with the more distant salons, to then start a joint project to monitor the satisfaction of these clients, otherwise, information that adds value to innovations may be lost.

About the challenges associated with the objectives of sharing MVV and identifying opportunities and threats that determine the action of the company, EMP was proactive in integrating internal and external partners. However, it is still learning to manage time, organize processes capable of mapping the behavior patterns of the distributors in terms of control of the satisfaction of the salons that use the products. With respect to the attendance of the characteristics that contribute to the development of exchanges of knowledge and learning inside and outside the company, I reached Table (4). In EMP, I found that there is an incentive for the education of employees to undertake courses, even outside the State, and that the company has partnerships with the Institute Euvaldo Lodi (IEL) and with the Federation of Industries of Espírito Santo (FINDES) so that the education of employees can always be improved. However, regarding the challenges associated with the objective of sharing the MVV of EMP with all employees, I came to the realization that they are more related to the manager's high concern to comply with what was planned in terms of results, than to take advantage of spaces to create new ideas, even in the company, the culture of seeking new ways of dealing with new situations, problems (internal weaknesses) and threats (external environment), a practice that usually facilitates the construction of a culture geared to change. 


\begin{tabular}{|c|c|c|c|c|c|c|}
\hline 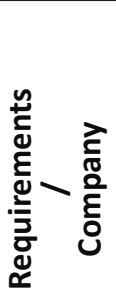 & $\begin{array}{l}\text { Flexible Or- } \\
\text { ganizational } \\
\text { Design }\end{array}$ & $\begin{array}{c}\text { Interaction } \\
\text { among employe- } \\
\text { es at all levels }\end{array}$ & $\begin{array}{l}\text { Open } \\
\text { communica- } \\
\text { tion systems }\end{array}$ & $\begin{array}{l}\text { Greater } \\
\text { interaction } \\
\text { with su- } \\
\text { ppliers and } \\
\text { customer }\end{array}$ & $\begin{array}{l}\text { Customer-cente- } \\
\text { red organizatio- } \\
\text { nal culture }\end{array}$ & $\begin{array}{l}\text { Strategic part- } \\
\text { nering with su- } \\
\text { ppliers }\end{array}$ \\
\hline EPP & $\begin{array}{l}\text { Low flexi- } \\
\text { bility in the } \\
\text { sense of not } \\
\text { being adap- } \\
\text { ted, and } \\
\text { having gre- } \\
\text { ater control } \\
\text { rather than } \\
\text { space for in- } \\
\text { teractions }\end{array}$ & $\begin{array}{l}\text { Focus on con- } \\
\text { trolling and } \\
\text { maintaining the } \\
\text { status quo; the- } \\
\text { re is reactivity, } \\
\text { in the sense of } \\
\text { expecting the } \\
\text { emergence of } \\
\text { something or } \\
\text { someone from } \\
\text { outside, to try } \\
\text { to analyze what } \\
\text { must be done. } \\
\text { There is also re- } \\
\text { activity regarding } \\
\text { the exchange of } \\
\text { ideas and search } \\
\text { for learning }\end{array}$ & $\begin{array}{l}\text { Open, but } \\
\text { focused on } \\
\text { execution, } \\
\text { and not in the } \\
\text { creation of } \\
\text { ideas aiming } \\
\text { at changes } \\
\text { and learning. }\end{array}$ & $\begin{array}{l}\text { Low interac- } \\
\text { tion with su- } \\
\text { ppliers and } \\
\text { distributors } \\
\text { (in the sen- } \\
\text { se of stra- } \\
\text { tegic direc- } \\
\text { tion), and } \\
\text { very low } \\
\text { interaction } \\
\text { with beauty } \\
\text { salons. }\end{array}$ & $\begin{array}{l}\text { Very low due to } \\
\text { poor planning } \\
\text { and organization } \\
\text { with no focus on } \\
\text { customer needs }\end{array}$ & $\begin{array}{l}\text { Long-term rela- } \\
\text { tionship. } \\
\text {-High Reliability } \\
\text {-Low exclusivity } \\
\text {-It manufactures } \\
\text { its own mold, pa- } \\
\text { ckaging and raw } \\
\text { materials }\end{array}$ \\
\hline EMP & $\begin{array}{l}\text { Low flexibi- } \\
\text { lity }\end{array}$ & $\begin{array}{l}\text { Planned, with } \\
\text { Control and Le- } \\
\text { arning }\end{array}$ & $\begin{array}{l}\text { Open, buil- } \\
\text { ding direc- } \\
\text { tion (there } \\
\text { is proactive } \\
\text { management } \\
\text { action in this } \\
\text { regard). ERP } \\
\text { technology le- } \\
\text { arning phase }\end{array}$ & $\begin{array}{l}\text { Receptive } \\
\text { with su- } \\
\text { ppliers, in } \\
\text { the sense of } \\
\text { listening to } \\
\text { their ideas, } \\
\text { and Proacti- } \\
\text { ve regarding } \\
\text { customer } \\
\text { contact. }\end{array}$ & $\begin{array}{l}\text { Proactive, in se- } \\
\text { arch of solutions } \\
\text { Engagement } \\
\text { from the mana- } \\
\text { gerial level up } \\
\text { Creation of } \\
\text { projects to } \\
\text { strengthen re- } \\
\text { lationships with } \\
\text { customers }\end{array}$ & $\begin{array}{l}\text {-Proactive; } \\
\text { Long-term rela- } \\
\text { tionship. } \\
\text {-High Reliability; } \\
\text { Low exclusivity } \\
\text {-Strategy to } \\
\text { manufacture its } \\
\text { own raw mate- } \\
\text { rials; -Project to } \\
\text { manufacture its } \\
\text { own mold and its } \\
\text { own packaging }\end{array}$ \\
\hline
\end{tabular}

Table 4: Comparison of the companies regarding the fulfillment of the requirements for a learning environment.

I add to this context, the fact that the company is undergoing a period of new decision-making in terms of expansion of its production area and having to choose whether or not to distribute their products. At the same time, the manager is dedicated to learning to better manage the planning time, in order to build a dialogue with exchanges of knowledge in the daily interactions with their employees, also begins a process of thinking to delegate and decentralize the decisions within this new cycle of the company; still aiming to maintain the strategy of innovating. The challenges identified in the search to be able to adapt the innovation capacity to the demands of the environment indicate that they are being managed from the focus on business strategy of continuing to invest in partnerships and collaborative practices. However, the challenges must be managed by taking into account the knowledge and practices that have already been learned and the importance of pursuing new ideas on an ongoing basis, from brainstorming and improved relationships processes.

Based on the analysis, I concluded that there is a concern to have strategic awareness on the part of the company as a whole and that the requirements for identifying the opportunities and threats that determine the company's action for continuous improvement are met or are under development or improvement. In addition, there is proactive interorganizational interaction, where it is 
possible to find information in the external environment and develop training related to the uses of products for customers, who are the salon hairdressers. However, the company is dependent on distributors, its main customer, for its knowledge about the final consumer (beauty salons), reason for EMP having its own distributor, at least in the state of ES and, in the process of deciding its expansion in terms of distribution to other states. However, the manager affirms to continue approaching the distributors, with offerings of trainings, even to know their processes of service delivery at beauty salons and understand how to orchestrate standards of quality and efficiency with the end consumer, who are the clients of beauty salon hairdressers.

With respect to the learning culture, appears to be present at the operational level of EMP through the practices of competitions to obtain new ideas, in which everyone is encouraged to contribute knowledge that helps to leverage creativity and innovations in the business. However, even with the existence of such competitions, the manager agrees that she is going through a process of learning about not losing sight of this flow of ideas, while at the same time deciding to expand the production and distribution operations of the company.

Despite practices that contribute to meaningful interactions for exchanges of knowledge, such as: courses, lectures and events to spread the best ideas, even the contests, the EMP's internal environment is still very much focused on the summit level in terms of interactions for innovations. All discussion of problems and projects are held only amongst managers and between managers and directors. There is still the challenge of knowing how to use the knowledge of other collaborators better, from the dialogues, in the spaces of the company and, constantly improving the discussions about information related to customer satisfaction.

Regarding the partnerships with suppliers, it was possible to analyze that there is no interest in establishing partnerships with suppliers, but there is a motivation to manufacture most of the raw materials and not to follow fashion.

\subsection{THE MANAGEMENT OF CHALLENGE IN THE LARGE COMPANY}

About the challenges associated with the objectives of sharing MVV and having to identify opportunities and threats that determine the action of the company, I have obtained that the management of the large company - EGP has conquered a culture aimed at "innovating the way to innovate". In EGP there is the presence of innovation requirements based on learning (Table5). According to the manager of the innovation network, in EGP there is the incorporation of the product of learning in the daily life of the team dedicated to innovations, from the practice of constant projects, uniting people from different areas to find new ideas and innovate the way to innovate. The innovation network manager conducts the MVV sharing process from discussions held at meetings by members of the multidisciplinary team.

The innovation network manager conducts the MVV sharing process from discussions held at meetings by members of the multidisciplinary team, both about MVV and the goals, problems and needs of new projects. Informal communications are valued by the manager and her work teams; there are programs of engagement with the objective of leading to individual reflection on the purpose and individual development; and there are periodic meetings for the exchange of information and knowledge, as well as incentive programs for the emergence of collaboration for the exchange of ideas, and goals of reserving time for learning/empowerment. 


\begin{tabular}{|c|c|c|c|c|c|c|}
\hline 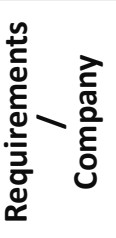 & $\begin{array}{c}\text { Flexible Or- } \\
\text { ganizational } \\
\text { Design }\end{array}$ & $\begin{array}{l}\text { Interaction } \\
\text { among em- } \\
\text { ployees at } \\
\text { all levels }\end{array}$ & $\begin{array}{c}\text { Open commu- } \\
\text { nication sys- } \\
\text { tems }\end{array}$ & $\begin{array}{c}\text { Greater } \\
\text { interaction } \\
\text { with su- } \\
\text { ppliers and } \\
\text { customers }\end{array}$ & $\begin{array}{l}\text { Customer- } \\
\text {-centered } \\
\text { organizational } \\
\text { culture }\end{array}$ & $\begin{array}{l}\text { Strategic partnering } \\
\text { with suppliers }\end{array}$ \\
\hline EGP & $\begin{array}{l}\text { Very flexible } \\
\text { organizatio- } \\
\text { nal structure } \\
\text { with regard } \\
\text { to the or- } \\
\text { ganization } \\
\text { of project } \\
\text { teams, } \\
\text { and with } \\
\text { controlled } \\
\text { flexibility } \\
\text { (planned, } \\
\text { emerging } \\
\text { and that } \\
\text { assesses and } \\
\text { questions } \\
\text { whether } \\
\text { strategy } \\
\text { manage- } \\
\text { ment should } \\
\text { follow the } \\
\text { same cou- } \\
\text { rse). }\end{array}$ & $\begin{array}{l}\text { Planned, } \\
\text { Controlled, } \\
\text { and Team } \\
\text { Learning, } \\
\text { seen the } \\
\text { meetings, } \\
\text { goals, cou- } \\
\text { rses and } \\
\text { training } \\
\text { focused on } \\
\text { the search } \\
\text { to innovate } \\
\text { the way to } \\
\text { innovate. }\end{array}$ & $\begin{array}{c}\text { Proactive } \\
\text { Integrated } \\
\text { systems in } \\
\text { communica- } \\
\text { tion networks } \\
\text { between } \\
\text { hierarchical } \\
\text { levels and } \\
\text { external envi- } \\
\text { ronment, with } \\
\text { customers } \\
\text { and suppliers } \\
\text { - Use of tech- } \\
\text { nologies such } \\
\text { as customer } \\
\text { database, } \\
\text { CRM and ERP } \\
\text { to facilitate } \\
\text { the process } \\
\text { of generating } \\
\text { new ideas. }\end{array}$ & $\begin{array}{l}\text { High inte- } \\
\text { raction with } \\
\text { customers, } \\
\text { including in- } \\
\text { dividual re- } \\
\text { sellers and, } \\
\text { practice of } \\
\text { open inno- } \\
\text { vation. }\end{array}$ & $\begin{array}{l}\text { Proactive, in } \\
\text { search of so- } \\
\text { lutions } \\
\text { Engagement } \\
\text { from the } \\
\text { managerial } \\
\text { level up, and } \\
\text { from the ma- } \\
\text { nagerial level } \\
\text { downwards. } \\
\text { Creation of } \\
\text { projects to } \\
\text { strengthen } \\
\text { relationships } \\
\text { with clients. }\end{array}$ & $\begin{array}{l}\text {-Proactive } \\
\text {-Relationship with } \\
\text { suppliers that have } \\
\text { passed the evaluation } \\
\text { of the company that } \\
\text { follows a series of } \\
\text { requirements and con- } \\
\text { ditions. } \\
\text {-High Reliability } \\
\text {-There is no exclu- } \\
\text { sivity, but there are } \\
\text { some that have larger } \\
\text { contracts, with more } \\
\text { clauses. } \\
\text {-Strategy to manufac- } \\
\text { ture their own raw } \\
\text { materials; - It manu- } \\
\text { factures its own mold } \\
\text { and its own packaging; } \\
\text {-Open innovation } \\
\text { practice involving even } \\
\text { suppliers. }\end{array}$ \\
\hline
\end{tabular}

Table 5: Meeting the requirements for a learning environment in EGP.

The manager of the network of innovations stated that the company's management is aimed at revenue and market growth and management works with the updating, renewal and transformation strategy of its multidisciplinary team. For the manager, training programs go beyond recycling and renewal, they also come down to transformation.

After analyzing both the routines of the team dedicated to innovation projects in EGP and the process of interactions, forms of communication, programs, policies, training, research and partnerships, I have seen the constant focus of EGP's innovation team on MVV, and the dedication to constant monitoring of activities linked to the innovation strategy.

By comparing the practices, policies and procedures of EGP with the learning disciplines of Peter Senge, the existence of an engagement program was obtained in order to gain individual reflection on the purpose and development of each individual. Therefore, it was possible to analyze that the program has a connection with the disciplines of personal domain and mental models, to the extent that it contributes, according to the manager, to develop the ability to make the individual look inside themselves and to identify what really matters to them. At EGP, there is a project structure with multidisciplinary teams focused on the open innovation strategy. The team has the goal of reserving time for learning through workshops, courses and lectures, practices that contribute to the exchange of knowledge, building a shared vision and for continuous improvement and teamwork.

The challenges identified in the search to be able to adapt the capacity of innovation to the requirements of the environment in which the company is inserted, is to keep the organizational environment open to the flow of information, without incurring high costs of time, in the process of monitoring, gathering, discussing and deciding on the best innovation strategy. At EGP, the business strategy is formed "[...] through meetings, based on goals established by senior management [...].The manager described that all the decision making on the medium and long term strategic ac- 
tions are concentrated in the top management, but the medium and long term objectives are shared in the company between managers and employees, including the formalized goals. The company chooses this type of sharing with managers and employees because, according to the manager, it "[...] gives direction to the company".

I asked if there is a predominance of top management stipulating how areas should seek to create value and what it understood as being business strategy. The manager answered by phone: "[...] my area is innovation, a driving force for growth; is what management always points out at strategic planning meetings". The manager said that the core of the company are the new technologies, product innovation and marketing concept [...]"; that exist "[...] work teams, with the other people in the company, involved in the projects [...]"; and thus, "[...] as soon as the whole managerial body involved 'on thinking' the goals and on thinking workshops [...] they develop plans for the development of innovation actions, people who are triggered for these events should share with others, but also with a view to preserving the confidentiality of the strategy".

The innovations in EGP are geared towards the development of new technologies, for the improvement of the product, always integrated with the areas of marketing and operations. In the responses, a greater emphasis was placed on product/technology innovations, marketing and organizational structure geared towards multidisciplinary teams. At the same time, innovations linked to changes in work teams, of products/technologies and marketing arise because there is constant monitoring and interaction with the external environment.

In terms of challenges in the innovation process, EGP's innovation manager believes that "[...] is to be maintaining a favorable environment for the exchange of ideas, but that is conquered by the focus on research that motivates employees to think on an always different level". The manager revealed that:

[...] every success of the innovation strategy always depends on the integration of the team, of their ability to seek improvements that bring contributions to all partners, of their ability to seek improvements that bring contributions to all partners [...], because the company's policy of being sustainable, of seeking to work sustainably from suppliers, spaces for the constant exchange of knowledge and innovations.

The network manager of innovations believes that "[...] when there is clarity in the direction of what is intended to achieve with space to invest in partnerships that meet the quality criteria and values defended by the company, such as: valorization of human potential, being against ambiguities, manipulations and discriminations, sharing of doubts and search for answers, trust between members [...], it is possible to innovate the way of innovating".

\section{CONCLUDING}

The objective of this research was to reveal reflections on the challenges related to the innovation process in industrial cosmetic companies. I concluded that the main challenges faced by the management of the innovation process in the small business are related to the non-development of a culture focused on innovation and not planning the capacity to decentralize. There is no strategic awareness building in small business because the requirements from identifying the company's core capabilities to learning and the direction of organizational learning for innovation capacity, are not fully met.

In the case of the medium sized company, the main challenge related to the innovation process is to manage, simultaneously, the growth of the company on the one hand, and the managerial practices aimed at the use of the knowledge of its team, on the other, in the process of innovation. 
Despite the existence of different activities focused on the continuous education of their team and the interactions with discussions about customer feedback, it lacks the managerial learning to keep its team towards the clarification of the established standards that must be modified to arrive at the systemic thought, bringing more proactivity in the search for new ideas. Even focused on strategic planning and employee education in general, still depends on a managerial behavior capable of better dealing with the requirements that facilitate the emergence of learning aimed at innovation in a continuous way.

In the case of the large company, I concluded that the challenges of maintaining the integration of the innovation process and, at the same time, the flexibility to transform the way things are done, are well orchestrated by management because there is constant discussion and shared vision, in a spirit of trust and teamwork. This successful orchestration seems to happen because management dedicates itself to maintaining a culture in which everyone is aware of the strategic direction of the company, at the same time that they feel important in the search and the conquest of innovations. There are spaces for the exchange of knowledge in the company environment, in which the lessons learned are discussed through a policy focused on the trust value between team members.

In order to be able to more effectively manage the innovation process, I am able to conclude that certain behaviors are necessary for the management to combine flexibility and control in the emergence of new ideas and in the culture of innovating: have a clear policy and communication from the focus on their mission, vision and values and, maintain internal and partner interactions in order to value the shared vision of the members of the innovation projects. These characteristics of managerial behavior approximate the emergence of significant learning, with a view to the emergence of innovations.

Given this, in terms of expected changes in the environment of companies looking for innovations, it is expected, in the case of small enterprises, which the management of the innovation process turns to the decentralization of decisions through the construction of an environment of trust and collaboration. In the case of medium-sized enterprise, I analyze that the management, focused on the formation of significant experiences among employees on an ongoing basis, from the management of the learning process and strategic learning, can cause new innovations to emerge involving everyone in an interactive flow in which knowledge and learning are shared.

Finally, in the case of the large company, the management of innovation must continue to value the maintenance of the organizational culture focused on the interaction of employees in the innovation process; maintain the organizational policy that values the exchange of ideas, the development of meaningful learning and strategic learning, with activities that excel in team spirit, shared vision, and systemic thinking, in a process seeking to innovate the way of innovating, in order to differentiate and sustain this differential over time.

\section{REFERENCES}

Abbade, E. B.; Zanini, R.R. \& Souza, A. M. (2012). Orientação para Aprendizagem, Orientação para Mercado e Desempenho Organizacional: Evidências Empíricas. RAC, v. 16, n.1, art. 7, Rio de Janeiro, jan./fev., pp.118-136.

Associação Brasileira de Higiene Pessoal, Perfumaria e Cosméticos (2012). Pequenas e Médias Empresas investem e inovam no setor de beleza. G1 Economia. 08 abr. Disponível em <http:// g1.globo.com/economia/pme/noticia/2012/04/pequenas-empresas-investem-e-inovam-no- 
setor-de-beleza.html> Acesso em: 02 dez. 2016.

Associação Brasileira de Consultoria e Assessoria em Comércio Exterior (2017). Disponível em $<$ https://www.abracomex.org/empresas-de-cosmeticos-focam-nas-exportacoes-para-ooriente-medio>. Acesso em 03 fev. 2018.

Amabile, T. M.; Hadley, C. N.; Kramer, S. J. (2002). Creativity under the gun. Harvard Business Review, Boston, v. 80, n. 8, Aug., pp. 52-61.

Anjo, C. E. S.; Barbosa, J. G. P.; Bouzada, M. A. C; Neto, C. G. (2012). Inovação e Formação de Estratégias Empresariais: Um estudo de caso no setor de material de defesa. Revista Gestão Industrial, v.08, n.1; pp.116-144.

Argyris, C.; Schon, D. (1978). Organization Learning: A Theory of Action Perspective. Reading/ Massachusetts: Addison-Wesley.

Ayas, K. (1999). Project design for learning and innovation: lessons learned from action research in an aircraft manufacturing company. In: EASTERBY-SMITH, M.; ARAÚJO, L.; Burcoyne, J.; (Org.). (1999). Organizational learning and the learning organization: developments in theory practice. London: Sage.

Bardin, L. (1977). Análise de conteúdo. Lisboa: Edições 70.

Barney, J. B. (2001). Is the resource-based "view" a useful perspective for strategic management research? perspective for strategic? The Academy of Management Review, Briarcliff Manor, v. 26, n. 1, Jan., p.41-56.

Berto, R. M. V. S.; Nakano, D. N. (1998). Metodologia da Pesquisa e a Engenharia de Produção. ABEPRO, São Paulo.

Bethlem, A. D. S. (2001). Estratégia empresarial: conceitos, processo e administração estratégica/ Agrícola Bethlem. 3. ed. São Paulo: Atlas.

Ausubel, D. P. (1968). Educational psychology: A cognitive view. New York: Holt, Rinehart \& Winston.

Caldeira, A.; Godoy, A. S. (2012). O processo de análise do ambiente e sua relação com a aprendizagem organizacional: um estudo de caso. REAd, Porto Alegre, Edição 73, no 3, pp. 779-812, set. /dez.

Carneiro, A. (2000). How does knowledge management influence innovation and competitiveness? Journal of Knowledge Management, v. 4, n. 2, pp. 87-98.

Cassia, A. R.; Zilber, S. N. (2016). Orientação estratégica e atividades inovativas: uma análise a partir dos dados da PINTEC no período de 1998 a 2011. Gest. Prod. vol.23, n3. São Carlos.

Costa Souza, J.; Bruno-Faria, M. F. (2013). Processo de inovação no contexto organizacional: uma análise de facilitadores e dificultadores. BBR - Brazilian Business Review, vol. 10, no 3, Julio September, pp. 113-136.

Crossan, M. L.; White, R. (1997). Organization Learning: Toward Theory. Working Paper.

Dacorso, A. L. R; Yu, A. S. O.; Silva, M. C. M; Araújo, G. F. (2010). Criatividade e inovação: um estudo experimental sobre a mensuração da originalidade e da completude em tomada de decisão. In: Encontro Nacional dos Programas de Pós-Graduação em Administração, 34, Rio de Janeiro, 
Anais... Rio de Janeiro: ENANPAD.

Eisenhardt, K. M.; Martin, J. A. (2000). Dynamic capabilities: what are they? Strategic Management Journal, vol. 21, n. 10/11, pp. 1105-1121.

Fischer, R. M. (2002). Mudança e Transformação Organizacional. In: As pessoas na Organização. 6. ed. Editora Gente: São Paulo: pp.147-164.

Fleury, A.; Fleury, M. T. L. (1995). Os Desafios da Aprendizagem e Inovação Organizacional. RAE Light.; v.2., n.5.; pp.14-20.

. (2011). Aprendizagem e inovação organizacional: as experiências de Japão, Coréia e Brasil. 2. ed., São Paulo: Atlas.

Fritz, M.; Souza, C. G. (2006). Inovação na Indústria de Cosméticos- Casos de empresas do setor. COBENGE, Anais do XXXIV COBENGE. Passo Fundo: Ed. Universidade de Passo Fundo, setembro.

Gilbert, M. A. (1994). Multi-Modal Argumentation. Philosophy of the Social Sciences, jun.

Gil, A. C. (2002). Como Elaborar Projetos de Pesquisa. 4. ed. São Paulo: Atlas.

Gonzalez, I. V. D. P.; Campos, F. C. de. (2015). Proposta de Modelo Conceitual de Formação de Estratégia de negócio a partir da integração da aprendizagem organizacional e a gestão da inovação. Gestão \& Planejamento, Salvador, v.16, n.3, pp.473-493, set./dez.

Gonzalez, I. V. D. P. (2014). Proposta de um modelo de formação de estratégia de negócio com base na integração entre aprendizagem organizacional e gestão da inovação. Tese (doutorado) Universidade Metodista de Piracicaba, Engenharia de Produção.

Gramigna, M. R. (2004). Líderes Inovadores: ferramentas de criatividade que fazem a diferença. São Paulo: M. Books do Brasil Editora Ltda.

Hamel, G.; Prahalad, C. K. (1995). Competing for the future. Boston: Harvard Business School Press (tradução: Competindo pelo futuro), Rio de Janeiro: Campus.

Hamel, G.; Prahalad, C. K. (1988). A competência essencial da corporação. In. Montgomery, C. A.; Porter, M. E. (Orgs.) Estratégia: a busca da vantagem competitiva. Tradução de Bazán Tecnologia e Linguística. Rio de Janeiro: Campus, pp. 293-316.

Isidro Filho, A.; Guimarães, T. de A. (2010). Conhecimento, Aprendizagem e Inovação em Organizações: uma proposta de articulação conceitual. Revista de Administração e Inovação - RAI, São Paulo, v. 7, n. 2, abr./jun., pp. 127-149.

Kaplan, R. S.; Norton, D. P. (2000). Organização Orientada para a Estratégia - como as empresas que adotam o Balanced Scorecard prosperam no novo ambiente de negócios. Rio de Janeiro: Campus.

Kaplan, R. S.; Norton, D. P. (2009). Execução Premium: Unindo os pontos - O sistema de gestão de Circuito Fechado. Pode ser o futuro da estratégia. HSM Management 74, maio-junho.

Leite, L. F.; Seidl, P.; Antunes, A. M. S. (2008). Análise do Desenvolvimento da Tecnologia de FCC sob a Ótica das Teorias de Aprendizagem Organizacional e Dinâmica da Inovação. Revista Brasileira 
de Inovação, Rio de Janeiro (RJ), 7 (1), janeiro/junho, pp. 25-62.

Lipshitz, R.; Friedman, V. J.; Popper, M. (2007). Demystifying organizational learning. Thousand Oaks, California: Sage.

Maciel, C. de O.; Sato, K. H.; Kato, H. T. (2012). Capacidades dinâmicas e rituais de interação entre alta e média gerência: proposta de um framework. Rev. Adm. Pública [online], vol.46, n.2, pp. 599-618. ISSN 0034-7612.

Marinova, D.; Phillimore, J. (2003). Models of innovation. In: Shavinina, L. V. (org.) The international handbook on innovation. Oxford: Elsevier Science.

Marconi, M. A.; Lakatos, E. M. (2003). Fundamentos de metodologia científica. 5. ed. São Paulo: Atlas.

Miguel, P. A. C. (2007). Estudo de caso na engenharia de produção: estruturação e recomendações para sua condução. Produção, v.17, n. 1, jan./abr., pp. 216-229.

Miguel, P. A. C.; Fleury, A.; Mello, C. H. P.; Nakano, D. N.; Turrioni, J. B.; Ho, L. L.; Morabito, R.; Martins, R. A.; Pureza, V. (2010). Metodologia de pesquisa em engenharia de produção e gestão de operações. ABEPRO, Campus, Rio de Janeiro: Elsevier.

Mintzberg, H. (1987). The strategy concept: five Ps for strategy. California Management Review - v. 30, n. 1, pp. 11-32.

Mir, M.; Casadesús, M. (2011). Standardised innovarion management systems: A case study of the Spanish Standard UNE 166002:2006, Revista Inovar, vol. 21, núm. 40, abril-junio.

Nonaka, I.; Takeuchi, H. (1997). Criação de conhecimento na empresa: como as empresas japonesas geram a dinâmica da inovação. 14 ed. Rio de Janeiro: Campus.

OCDE. (2005). Oslo Manual: Guidelines for Collecting and Interpreting Innovation Data. OCDE publishing, 3rd Edition, Paris.

Porter, M. (1996). What is Strategy? Harvard Business Review.

Prahalad, C. K.; Hamel, G. (1990). The core competence of the corporation. Harvard Business Review, may/june, 68, pp. 79-91.

A competência essencial da corporação. In: Montgomery, C.; Porter, M. Estratégia: a busca da vantagem competitiva. 3. Ed. Rio de Janeiro: Campus, p. 293-316, 1998.

Salim, I. M.; Sulaiman, M. (2011). Organizational Learning, Innovation and Performance: A Study of Malaysian Small and Medium Sized Enterprises. International Journal of Business and Management. v. 6, No. 12; dec..

Senge, P. M. (2000). A quinta disciplina: Caderno de campo. Estratégias e ferramentas para construir uma organização que aprende. Rio de Janeiro: Qualyty Mark.

Serrano, B. P.; Gobbo Junior, J. A. (2014). Redes de inovação: mapeamento de inventores de patentes em uma empresa do setor de cosméticos. GEPROS. Gestão de Produção, Operações e Sistemas, Bauru, Ano 9, no1, jan-mar, pp.101-113. 
Sirmon, D. G.; Hitt, M. A.; Ireland, R. D. (2007). Managing firm resources in dynamic environments to create value: looking inside the black box. Academy of Management Review, v. 32, n. 1, pp. 273- 292.

Shavinina, L. V.; Seeratan, K. L. (2003). On the nature of individual innovation. In: Shavinina, L. V. (org); The international handbook on innovation. Oxford: Elsevier Science.

Stewart, T. (1998). Capital Intelectual. Rio de Janeiro: Campus.

Teece, D. J.; Pisano, G.; Shuen, A. (1997). Dymamic Capabilities and Strategic Management, Vol. 18, No.7, pp. 509-533.

Tidd, J.; Bessant, J.; Pavitt, K. (2008). Gestão da inovação. 3. ed. São Paulo: Bookman.

Turrioni, J. B.; Mello, C. H. P. (2012). Metodologia de Pesquisa em Engenharia de Produção: Estratégias, métodos e técnicas para condução de pesquisas quantitativas e qualitativas. UNIFEI.

Vergara, S. C. (2006). Métodos de pesquisa em administração. 2. ed. São Paulo: Atlas. . (2011). Projetos e Relatórios de Pesquisa em Administração, 13a edição, Editora Atlas.

Vilha, A. M. (2013). Práticas de gestão de inovação tecnológica: proposição de um modelo para pequenas e médias empresas brasileiras. Revista Gestão \& Conexões - Management and Connections, Vitória (ES), jan./jun., v. 2, n. 1, pp. 116-146.

Zawislak, P. A. (1995). A relação entre o conhecimento e desenvolvimento: essência do progresso técnico. Análise. v. 6, n.1, pp.125-149.

\section{AUTHORS}

\section{Inayara Valéria Defreitas Pedroso Gonzalez.}

Federal University of Espírito Santo.

Professor of the Graduate Program in Administration - PPGAdm and the Department of Administration at UFES (Federal University of Espírito Santo). Researcher at the Research Group on Organizational Technologies and processes - TecPrO. $\mathrm{PhD}$ In Production Engineering, Management and Strategies Concentration Area by UNIMEP. Vitória, Espírito Santo, Brazil. E-mail: gonzalezinayara@gmail.com ORCID: http://orcid.org/0000-0003-4873-0101 


\section{Contribution of authors}

\section{Contribution}

1. Definition of research problem

2. Development of hypotheses or research questions (empirical studies)

3. Development of theoretical propositions (theoretical work)

4. Theoretical foundation / Literature review

5. Definition of methodological procedures

6. Data collection

7. Statistical analysis

8. Analysis and interpretation of data

9. Critical revision of the manuscript

10. Manuscript writing

11. Other (please specify)
[Author 1] [Author 2] [Author 3] [Author 4]

v

$\sqrt{ }$

$\boldsymbol{V}$

$\boldsymbol{V}$

$\sqrt{ }$

$\sqrt{ }$

$\sqrt{ }$

$\sqrt{ }$ 